DOI: $10.4274 /$ tjps. 65487

\title{
Evaluation of Alchemilla persica Rothm. antidiabetic activity on mice induced by alloxan
}

\section{Alloksanla indüklenen farelerde Alchemilla persica Rothm.'nın antidiyabetik etkisinin değerlendirilmesi}

Serkan Özbilgin, Hanefi Özbek, Neriman İpek Kırmızı, Burçin Ergene Öz, Ekin Kurtul, Bade Cevriye Özrenk, Gülçin Saltan İşcan, Özlem Bahadır Acıkara ${ }^{1}$ Ankara University Faculty of Pharmacy, Department of Pharmacognosy, Ankara, Turkey ${ }^{2}$ Istanbul Medipol University Faculty of Medicine, Department of Pharmacology, İstanbul, Turkey 3istanbul Medipol University Faculty of Medicine, Department of Vocational School of Health Services İstanbul, Turkey

\section{Abstract}

INTRODUCTION: Alchemilla species are used in Turkish folk medicine for treatment of many disease together with diabetes. Alchemilla persica belonging to this genus, widely distributed in East part of Anatolia as well as Caucasica, north and northeast of Iran and north Iraq.

METHODS: In present study Alchemilla persica aerial part and root methanolic-water extracts were evaluated for their hypoglycemic activities on alloxan induced diabetic mice in order to verify its usage in folk medicine.

RESULTS: Any of the tested extracts did not exhibit significant lowering effect on blood glucose levels. On the other hand A. persica aerial parts increased blood glucose level at the döşe of $100 \mathrm{mg} / \mathrm{kg}$ and $200 \mathrm{mg} / \mathrm{kg}$ notably.

DISCUSSION AND CONCLUSION: A. persica usage for its antidiabetic activity is not confirmed in present study.

Keywords: Alchemilla persica, alloxan, antidiabetic activity, diabet, hypoglycemic activity

\section{INTRODUCTION}

Alchemilla L. (Rosaceae) genus, with more than 1000 species, is distributed mainly in western Eurasia as well as South and East Africa, Madagascar, South India, Sri Lanka and Java. ${ }^{1-2}$ In Turkey 50 species of Alchemilla genus which are mainly distributed in north-east Anatolia, were recorded and this number has reached to 74 with new records. ${ }^{1}$ Alchemilla persica Rothm. belonging to this genus, naturally grows in East part of Anatolia, Caucasica, north and northeast of Iran and north Iraq. ${ }^{3}$ 
A. vulgaris L. (Lady's mantle, Bear's foot, Lion's foot) is the best known species from Alchemilla genus is mainly used for women illness, wounds and skin disorders in Europe $^{4-6}$. Its usage for non-spesific diarrhea is approved by Commission E. ${ }^{7}$ Additionally, ESCOP Monographs described this plant usage for non-spesific diarrhea, gastrointestinal disorders and dysmenorrhea based on clinical studies and long-term using. ${ }^{8}$ Alchemilla species are used for their wound healing, sedative, ${ }^{9-12}$ antidiareic, tonic, diuretic activities, ${ }^{13-15}$ treatment for menstruation disorders, ${ }^{16}$ gynecological problems, ${ }^{17-18}$ liver inflammation, ${ }^{17}$ against asthma, bronchitis, cough, ${ }^{19}$ diabetes, as well as kidney, intestinal and gastric disorders ${ }^{20-21}$ and skin diseases. ${ }^{10}$

Previous studies have revelaed that $A$. persica aerial parts and roots showed antioxidant activity by DPPH radical scavenging $\left(\mathrm{IC}_{50} 0.055 \mathrm{M}\right.$ and $0.151 \mathrm{M}$, respectively) and reducing MDA levels $\left(5.9 \mathrm{nmol} / \mathrm{ml}\right.$ and $19.08 \mathrm{nmol} / \mathrm{ml}$ respectively). ${ }^{22}$ A. persica aerial parts extract exhibited a reduction in the endometrioma. However, significant reduction on the levels of cytokine; tumor necrosis factor- $\alpha$ (TNF- $\alpha$ ), vascular endothelial growth factor (VEGF), interleukin-6 (IL-6) were not recorded. ${ }^{23}$ A. persica displayed significant wound healing activity with the tensile strength values of $33.3 \%$, and with the contraction values of $43.5 \%$, in linear incision and circular excision wound models respectively. Hydroxyproline estimation and histopathological analysis also confirmed the results. A. persica showed significant anti-inflammatory activity with the values of $26.6 \% .{ }^{24}$ Phenolic constituents; caffeic acid esters with sugars, flavonoids glycosides, catechin and epicatechin, condensed tannins related to gallic acid, such as pedunculatin/ pedunculagin, agrimoniin, casuarictin, castalagin/vescalagin, and sanguiin $\mathrm{H}-10$ isomers were identified by HR-MS Q-TOF in A. persica aerial parts and its essential oil consisted of diterpenoids (19.6\%) and sesquiterpenoids (17.2\%) mainly. ${ }^{25}$

Current study was designed to evaluate hypoglycemic activities of $A$. persica roots and aerial parts using alloxan induced diabetic mice test model to prove its traditional usage for treatment of diabetes in Turkish folk medicine. 


\section{MATERIALS AND METHODS}

\section{Plant Material}

Plant material was collected from Erzurum-Kop Passage, Turkey. The taxonomic identification of these plants was confirmed by $\mathrm{H}$. Duman, in the Department of Biological Sciences, Faculty of Art and Sciences, Gazi University. Voucher specimens were kept in the herbarium of Ankara University, Faculty of Pharmacy (AEF 25896).

\section{Extraction}

Aerial parts and roots of A.persica were extracted with methanol:water (80:20) solvent system for 8 hours at room temperature by stirring and filtered. Methanol was evaporated under vacuum at $35-40^{\circ} \mathrm{C}$ then remaining water was lyophilized to obtain crude extracts.

\section{Animals}

Balb/C mice $(22-30 \mathrm{~g})$ were used for antidiabetic activity. The study protocol (30/09/2015-69) was approved by the Ethical Committee of, İstanbul Medipol University. The animals were housed in standard cages $(48 \mathrm{~cm} \times 35 \mathrm{~cm} \times 22 \mathrm{~cm})$ at room temperature $\left(22 \pm 2^{\circ} \mathrm{C}\right)$, with artificial light from 7.00 am to $7.00 \mathrm{pm}$, and provided with pelleted food and water ad libitum. The procedures followed were in accordance with animal rights as per the Guide for the Care and Use of Laboratory Animals

\section{Chemicals}

Alloxan purchased from Sigma (Steinheim-Germany). Alloxan and Alchemilla persica extracts dissolved in distilled water (w/v).

\section{Antidiabetic activity}

Diabetes was induced by injecting of $150 \mathrm{mg} / \mathrm{kg}$ of alloxan solution in ISS (Isotonic saline solution) i.p.after fasting for $18 \mathrm{~h}$ of mice. This procedure was repeated three times by 48 hours intervals. After 7 days of the treatment, mice blood glucose levels were measured. Mice have $200 \mathrm{mg} / \mathrm{dL}$ and over were taken into the study as diabetic mice. Diabetic animals were randomly divided into five groups of six animals each. Group I mice received $0.1 \mathrm{~mL}$ ISS i.p. The animals of group II and III were treated with 
$100 \mathrm{mg} / \mathrm{kg}$ body weight of $A$. persica aerial part extracts at $100 \mathrm{mg} / \mathrm{kg}$ and $200 \mathrm{mg} / \mathrm{kg}$ dose, group IV and $V$ were terated by $100 \mathrm{mg} / \mathrm{kg}$ and $200 \mathrm{mg} / \mathrm{kg}$ A. persica root extract respectively. The animals were treated with ISS and A.persica extracts with single dose at the beginning of the procedureThe blood was taken from tail ven by scalpel blade and blood glucose levels were determined before treatment, 1,2 and $4 \mathrm{~h}$ after treatment by applying glucose oxidase peroxidase method using Accu-Check ${ }^{\circledR}$ device (Abbott, United Kingdom).

\section{Statistical Analyses}

Statistical analysis were evaluated by using SPSS 18.0 programme. Results are reported as mean \pm SEM (standard error of mean) and as percentage (\%). One-way analysis of variance (post-hoc Least Significant Difference-LSD test) was used for statistical analyses. Probability levels of less than $0.05(P<0.05)$ were considered significant.

\section{RESULTS}

In order to investigate hypoglycemic activities of $A$. persica aerial parts and roots extract on alloxan induced diabetic mice blood glucose levels were measured before and 1, 2 and $4 \mathrm{~h}$ after treatment. Table 1 displayed the effect of the $A$. persica extracts on blood sugar levels. Current study results have revealed that none of the extracts were induced significant reduction on levels of blood sugar $(p>0.05)$. On the other hand notable increasing on blood glucose levels were observed after $1 \mathrm{~h}$ and $2 \mathrm{~h}$ treatment of $A$. perisca aerial parts at $100 \mathrm{mg} / \mathrm{kg}$ dosage and $1 \mathrm{~h}$ treatment after $200 \mathrm{mg} / \mathrm{kg}$ dosage. Decreasing on blood glucose level was detected only by treatment of $A$. persica roots at $200 \mathrm{mg} / \mathrm{kg}$ dosage after $4 \mathrm{~h}$ treatment. However the results were not significant.

\section{DISCUSSION}

In Turkish folk medicine, the usage of Alchemilla compactilis Juz., Alchemilla speciosa Buser and other Alchemilla species for treatment of diabetes is recorded. ${ }^{20-21}$ This study is not confirmed the usage of $A$. persica in folk medicine for treatment of diabetes. Previous study related to hypoglycemic effect of $A$. xanthochlora (A. vulgaris), have also reported that decoction of the leaves were not active on streptozotosin induced 
diabetic mice. ${ }^{8}$ A. mollis aerial parts and roots were also tested for their antidiabetic activities and similar results to $A$. persica were obtained. ${ }^{26}$ All study results have indicated that Alchemilla species; A. mollis, A. vulgaris and A. persica has no lowering effect on blood glucose levels. On the contrary, A. mollis and A. persica aerial parts increased blood glucose levels at $100 \mathrm{mg} / \mathrm{kg}$ and $200 \mathrm{mg} / \mathrm{kg}$ dosage after 4 hour of treatment.

\section{CONCLUSION}

According to the current study results it could be suggested $A$. persica aerial parts and roots are not useful for decreasing blood sugar levels in short time treatment. Furthermore the usage of the $A$. persica is not suitable in phytotheraphy for other medicinal purposes in diabetic patients.

\section{References}

1- Hayırlıoğlu-Ayaz S, Inceer H. Three new Alchemilla L. (Rosaceae) records from Turkey. Pak J Bot. 2009; 41(5): 2093-2096.

2- Faghir MB, Attar F, Shavvon RS, Mehrmanesh A. Pollen morphology of the genus Alchemilla L. (Rosaceae) in Iran. Turk J Bot. 2015; 39: 267-279.

3- Davis PH. Flora of Turkey and the East Aegean Islands Volume 4. Edinburgh. Edinburgh University Press; 1982:99.

4- PDR for Herbal Medicines (2nd ed.). Montvale, NJ; Thomson Medical Economics; 2000.

5- Said O, Khalil K, Fulder S, Azaizeh H. Ethnopharmacological survey of medicinal herbs in Israel, the Golan Heights and the West Bank region. J. Ethnopharmacol. 2002; 83:251-265.

6- Tasic S. Ethnobotany in SEE-WB countries; Traditional Uses of Indigenous Plants. Lek Sirov, 2012; 32:71-81.

7- Blumenthal M, Werner RB. The Complete German Commission E Monographs: Therapeutic Guide to Herbal Medicines (1st ed). Austin, Texas; American Botanical Council, Lippincott Williams \& Wilkins; 1998:158.

8- Mills MS, Hutchins R. European Scientefic Cooperative on Phytotherapy (ESCOP) Monographs Online Series, Alchemilla herba-Alchemilla/Lady's Mantle. United Kingdom; ESCOP Notaries House; 2013. 
9- Saraç DU, Ozkan ZA, Akbulut S. Ethnobotanic features of Rize/Turkey province. Biological Diversity and Conservation. 2013; 6(3):57-66.

10- Kaval I, Behçet L, Cakılcıoğlu U. Ethnobotanical study on medicinal plants in Geçitli and its surrounding (Hakkari-Turkey). Journal of Ethnopharmacology. 2014; 155: 171-184.

11-Güzel Y, Güzelsemme M, Miski M. Ethnobotany of medicinal plants used in Antakya: A multicultural district in Hatay Province of Turkey. Journal of Ethnopharmacognosy. 2015; 174:118-152.

12-Mükemre M, Behçet L, Cakılcıoğlu U. Ethnobotanical study on medicinal plants in villages of Çatak (Van-Turkey). Journal of Ethnopharmacognosy. 2015; 166:361-374.

13-Baytop T. Türkiye'de Bitkiler ile Tedavi (2st ed). İstanbul; Nobel Tıp Kitabevleri Ltd Şti; 1999.

14-Altundağ E, Ozturk M. Ethnomedicinal studies on the plant resources of east Anatolia, Turkey. Procedia Social and Behavioral Sciences, 2011; 19:756-777.

15-Akbulut S, Bayramoğlu MM. The trade and use of some medical and aromatic herbs in Turkey. Ethno.Med. 2013; 7(2):67-77.

16-Polat R, Satı F, Cakılcıoğlu U. Medicinal plants and their use properties of sold market in Bingöl (Turkey) district. Biological Diversity and Conservation. 2011; 4(3):25-35.

17-Sağıroğlu M, Arslanturk A, Akdemir ZK, Turna M. An ethnobotanical survey from Hayrat (Trabzon) and Kalkandere (Rize/Turkey). Biological Diversity and Conservation. 2012; 5(1):31-43.

18-Kalankan G, Ozkan ZC, Akbulut S. Medicinal and aromatic wild plants and traditional usage of them in Mount Ida (Balıkesir/Turkey). JABS. 2015; 9(3):2533.

19-Polat R, Çakılcıoğlu U, Kaltalıoğlu K, Ulusan MD, Türkmen Z. An ethnobotanical study on medicinal plants in Espiye and its surrounding (Giresun-Turkey). Journal of Ethnopharmacology. 2015; 163:1-11.

20-Akbulut S, Bayramoğlu MM. Reflections of socio-economic and demographic structure of urban and rural on the use of medicinal and aromatic plants: the sample of Trabzon Province. Ethno.Med. 2014; 8(1):89-100.

21-Akbulut S, Ozkan ZC. Traditional usage of some wild plants in Trabzon region (Turkey). Kastamonu Univ. Journal of Forestry Faculty. 2014; 14(1):135-145. 
22-Ergene B, Bahadır Acıkara Ö, Bakar F, Saltan G, Nebioğlu S. Antioxidant Activity and Phytochemical Analysis of Alchemilla persica Rothm. J Fac Pharm. 2010; 39(2):145-154.

23-Küpeli Akkol E, Demirel MA, Bahadır Acıkara Ö, Süntar I, Ergene B, Ilhan M, Ozbilgin S, Saltan G, Keleş H, Tekin M. Phytochemical analyses and effects of Alchemilla mollis (Buser) Rothm. and Alchemilla persica Rothm. in rat endometriosis model. Archives of Gynecology and Obstetrics. 2015; 292(3):619-628.

24-Ergene Öz B, Ilhan M, Özbilgin S, Küpeli Akkol E, Bahadır Acıkara Ö, Saltan G, Keleş $\mathrm{H}$, Süntar I. Effects of Alchemilla mollis and Alchemilla persica on the wound healing process. Bangladesh Journal of Pharmacology. 2016; 11(3):577-584.

25-Heshmati Afshar F, Maggi F, Ferrari S, Peron G, Dall'Acqua S. Secondary Metabolites of Alchemilla persica Growing in Iran (East Azarbaijan). Natural Product Communications. 2015; 4:1-10.

26-Özbek H, Bahadır Acıkara Ö, Keskin I, Kırmızı NI, Özbilgin S, Ergene Öz B, Kurtul E, Özrenk BC, Tekin M, Saltan G. Evaluation of hepatoprotective and antidiabetic activity of Alchemilla mollis. Biomedicine \& Pharmacotherapy. 2017; 86: 172-176.

27-Abdel-Wahhab MA, Nada SA, Arbid MS. Ochratoxicosis: prevention of developmental toxicity by L- methionine in rats. J Appl Toxicol. 1999; 19 (1):712. 
Table 1. Blood sugar levels of alloxan induced diabetic mice

\begin{tabular}{|c|c|c|c|c|}
\hline \multirow{3}{*}{ Groups } & \multicolumn{4}{|c|}{ Blood sugar levels (mg/dL) } \\
\hline & \multirow{2}{*}{$\begin{array}{c}\text { Before } \\
\text { treatment } \\
\text { with } A \text {. } \\
\text { persica }\end{array}$} & \multicolumn{3}{|c|}{ After treatment with $A$. persica } \\
\hline & & $\begin{array}{c}1 \mathrm{~h} \\
(0-1)\end{array}$ & $\begin{array}{c}2 \mathrm{~h} \\
(0-2)\end{array}$ & $\begin{array}{c}4 \mathrm{~h} \\
(0-4)\end{array}$ \\
\hline Control (ISS) & $470,00 \pm 23,62$ & $\begin{array}{c}471,00 \pm 13,78 \\
(0,74 \pm 3,99)\end{array}$ & $\begin{array}{c}493,80 \pm 15,55 \\
(5,54 \pm 3,73)\end{array}$ & $\begin{array}{c}494,20 \pm 27,32 \\
(4,97 \pm 2,18)\end{array}$ \\
\hline $\begin{array}{l}\text { A. persica(AE) } 100 \\
\mathrm{mg} / \mathrm{kg}\end{array}$ & $306,67 \pm 36,13$ & $\begin{array}{c}501,67 \pm 27,97 \\
(70,97 \pm 15,01)^{*}\end{array}$ & $\begin{array}{c}484,67 \pm 22,12 \\
(67,15 \pm 17,39)^{*}\end{array}$ & $\begin{array}{l}387,66 \pm 20,77 \\
(36,35 \pm 17,91)\end{array}$ \\
\hline $\begin{array}{l}\text { A. persica(AE) } 200 \\
\mathrm{mg} / \mathrm{kg}\end{array}$ & $297,40 \pm 38,09$ & $\begin{array}{c}410,00 \pm 25,37 \\
(42,81 \pm 10,85)^{*}\end{array}$ & $\begin{array}{l}354,20 \pm 33,90 \\
(22,50 \pm 12,27)\end{array}$ & $\begin{array}{r}290,60 \pm 59,97 \\
(1,36 \pm 26,06)\end{array}$ \\
\hline $\begin{array}{l}\text { A. persica }(\mathrm{R}) 100 \\
\mathrm{mg} / \mathrm{kg}\end{array}$ & $337,00 \pm 27,28$ & $\begin{array}{l}379,83 \pm 52,56 \\
(14,45 \pm 15,87)\end{array}$ & $\begin{array}{l}425,33 \pm 52,26 \\
(29,80 \pm 17,04)\end{array}$ & $\begin{array}{r}355,83 \pm 61,67 \\
(8,87 \pm 18,78)\end{array}$ \\
\hline $\begin{array}{l}\text { A. persica (R) } 200 \\
\mathrm{mg} / \mathrm{kg}\end{array}$ & $405,17 \pm 24,40$ & $\begin{array}{c}445,00 \pm 44,83 \\
(9,01 \pm 7,30)\end{array}$ & $\begin{array}{c}427,83 \pm 50,04 \\
(4,64 \pm 9,13)\end{array}$ & $\begin{array}{c}305,80 \pm 63,67 \\
(- \\
23,73 \pm 13,49)\end{array}$ \\
\hline
\end{tabular}

AE: aerial parts; $\mathrm{R}$ : roots

Mean \pm Standart Error of Mean (mean \pm SEM).

Results of Post-hoc LSD test:

*: Comparision with SF group $(p<0.05)$ 